\title{
MIR125A wt Allele
}

National Cancer Institute

\section{Source}

National Cancer Institute. MIR125A wt Allele. NCI Thesaurus. Code C82065.

The human MIR125A wild-type allele is located in the vicinity of $19 q 13.33$ and is approximately 85 bases in length. This allele, which encodes MIR125A pre-miRNA, plays a role in the regulation of gene expression. Alteration in the expression of this gene is associated with development of medulloblastoma and breast cancer. 